The psychosocial dimension of power

\title{
The psychosocial dimension of power: an emotional analysis of the discourse on globalization of the Davos elite
}

Mario D’Andreta, mdandreta@protonmail.com

\begin{abstract}
This work focused the psychosocial dynamics underlying the political and cultural action of the global elite, through a pilot study of the image of globalization of the World Economic Forum (WEF) addressed to identify possible strategies for developing those dynamics in a more democratic and socio-economically fair way and strengthening the global civil coexistence. The results show the centrality of specific relational and organizational models, based on the orientation to possess the other, the need for power as dominant social motivation and a mythical conception of supranational financial institutions which let them to operate without real commission, nor evaluation of efficacy, from their beneficiaries. On the basis of this scenario, two ways of development have been identified: the valorization of the other as a resource for the reciprocal development and the passage from a compliance based logic of action to a commonly agreed goals and products based one.
\end{abstract}

\section{Keywords}

Davos elite, globalization, World Economic Forum, discourse analysis, Text Emotional Analysis, relational models, emotional dynamics, organizational culture, social coexistence, change

This essay draws upon the assumption that social behaviour is driven by socially shaped and shared meanings of the subjective experience of reality. This assumption results from the empirical research and theoretical elaboration in the field of social sciences, starting from the theory of symbolic interactionism (Blumer 1969, Charon 2004, Hall 2007, Mead 1934, Reynolds \& Hermann-Kinney \& Nancy 1958, Strykern 1980) in the 30's of the last century, passing for the social constructivism (Berger \& Luckmann 1966, Burr 1995, Gergen 1999, Glasersfeld 1995, Harré 2002, Harré \& Gillett 1994, Kukla 2000, Leeds-Hurwitz 2009, Lock \& Strong 2010, Searle 1995) and the theory of social representations (Abric 1994, Jodelet 1991, Duveen \& Lloyd 1990, Farr \& Moscovici 1984, Moscovici 1961, 1963, 1988, Wagner \& Hayes 2005 ) in the 60's and 70's of the last century, up to the Matte Blanco's Bi-logic theory of mind (Lombardi 2015; Matte Blanco 1975, 1988; Rayner 1995; Rayner \& Tuckett 1988) and the 
Carli's theory of collusion (Carli 1987, 1990, 1995, 2001, Carli \& Giovagnoli 2011, Carli \& Paniccia 2002, 2003, Carli et al, 2016, Grasso \& Salvatore 1997, Paniccia 1992) from the '70 of the last century until our days. This perspective of analysis has been used to investigate the cultural factors underlying the political, economic and cultural action of the global power elite represented by the World Economic Forumi, with the aim of better understanding its meaning and purpose, in relation to the current situation of economic, political, social, cultural and environmental crisis, and identifying possible strategies of intervention to enhance democracy and socio-economic justice of the global policy-making process, increase quality of life and strengthen social coexistence at a global level. The concept of social coexistence is here conceived according to the theory of Carli (Carli 1987, 1990, 1995, 2001; Carli \& Paniccia 2002, 2003; Carli et al, 2015), who sees it as based on the relationships between systems of belonging and stranger, mediated by rules of the game. In this perspective, the systems of belonging represent social system that function in a self-referential and conservative way, and thus, configures other's diversity as a threat for their immutable reproduction, on the basis of emotional dynamics of power and affiliation (e.g. the relational dynamics of a Christmas or Thanksgiving family dinner) and the stranger represents the unknown diversity of the other from oneself which could threat their stability. The rules of the games should, hence, allow to transform systems of belonging, which try to exclude differences by functioning through the search and building of similarities, into systems of coexistence, which should make coexist differences, conceiving them as possible resources for the common development. This symbolic process of construction of social coexistence is conceived by Carli and Paniccia as based on two basic emotional modalities of social relations: the exchange with the other and the possession of the other (Carli \& Paniccia 2002, 2003; Petitta \& Ghezzi 2012).

This work takes also cue from the development of an ideational approach in the study of globalization (Berry 2008, 2011; Hay 1997, 1999, 2002; Hay \& Marsh 2000; Hay \& Rosamond 2002; Steger 2002, 2005, 2008; Cameron \& Palan 2004), which proposes a radical change of perspective on the analysis of globalization, moving the focus from the dispute about the fact that the world is or not globalized or globalizing to the beliefs about globalization. It conceives as more important understanding how people interpret globalization, than globalization itself, because the belief that the world is globalized, will make act as it is. Globalization is thus considered an ideational force which influences human action and policy making (Martell 2010; Berry 2008). Particularly this new perspective on the study of globalization draws upon the outcomes of the analysis of the New Labour's political discourse of globalization in Britain (Hay 1997; Hay \& Smith 2005; Hay \& Watson 1998, Berry 2008), which provides evidence that the political discourse of globalization, rather than globalization itself, shapes political action by defining what can be politically and economically acceptable in terms of policies (Hay \& Watson 1998) and that political institutions strategically used different discourses of globalization for 
different purposes, in order to justify and legitimate its political action (Hay 2002; Hay \& Smith 2005, Hay \& Rosamond 2002).

\section{Theoretical and methodological framework}

The study of the cultural determinants of political and economic action of the Davos elite has been conducted through the analysis of the discourse on globalization produced by the members of the World Economic Forum's board of trustees, according to the Text Emotional Analysis (TEA), a methodology of discourse analysis aimed at identifying emotional dimensions of the symbolic representations shared within given contexts around specific topics, with the purpose of elaborating strategies of intervention upon them in order to produce some changes and improvement in the ways to deal with them. This methodology is based on the psycho-sociological theory of collusion (Carli 1987, 1990, 1995, 2001; Carli \& Paniccia 2002, 2003; Carli \& Giovagnoli 2010; Grasso \& Salvatore 1997, Paniccia 1992) and the statistical techniques of lexicometric analysis (Benzécri 1981, Bolasco 1999, Lebart \& Salem 1988). The theory of collusion represents a psychoanalytic approach to the development of social coexistence systems based on the Matte Blanco's Bi-logic theory of mind (Matte Blanco $1975,1988)$. The theoretical construct of collusion is conceived as the process of reciprocal emotional symbolizations of contexts which are socially shared by those who belong to them (Carli et al. 2015). This process would drive social action by shaping the construction, through discursive processes, of shared meanings of social life. The statistical processing of data reorganizes the structure of the textual corpus producing as outcome semantic clusters of dense wordsii, that represent the specific collusive dynamics expressed by the text. The cooccurrences of these words within each cluster and the relationships among clusters are then interpreted through models of social relations based on the theory of collusioniii (Carli \& Paniccia 2002, 2003), in order to obtain an interpretative model of the phenomenon under examination. Statistical analysis has been performed with the software T-Lab (Lancia 2004). The etymological analysis of dense words was made with the online dictionaries WordReference and Online Etymology Dictionaryiv. The analysis has been performed on a text corpus of 171054 words, composed of interviews, statements, articles, speeches and other text documents of the members of the World Economic Forum's Board of Trustees of 2015v, gathered through keywords search on Google search engine, for the period of time 2000-2015.

\section{Results}

The symbolic representation of the globalization of the Davos elite arising from the analysis results composed of four cultural dimensions, corresponding to the clusters of dense words 
obtained through the statistical analysis of text. These clusters result distributed in the factorial space as showed by the following graphic.

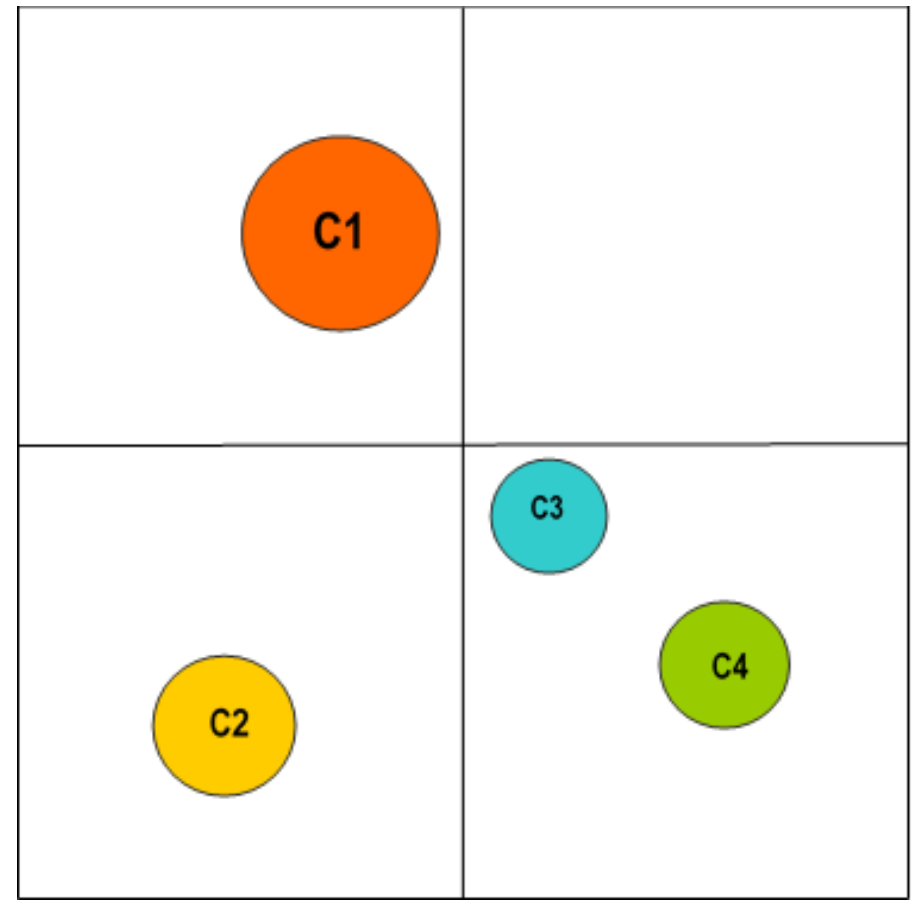

Figure 1. Distribution of the clusters in the factorial space

\section{Relationship between context units and cluster}

Each cluster represents a different part of the context units, that are fixed chunks of text that divide the total body of the corpus of texts submitted to analysis, as shown in table 1 . The first cluster represents over the half of the context units, while each other clusters only minor parts of them.

\begin{tabular}{|l|r|}
\hline & Context units \\
\hline Cluster 1 & $55,38 \%$ \\
\hline Cluster 2 & $19,88 \%$ \\
\hline Cluster 3 & $12,17 \%$ \\
\hline Cluster 4 & $12,57 \%$ \\
\hline Total & $100 \%$ \\
\hline
\end{tabular}

Table 1. Distribution of the context units in the clusters

\section{Relationship between clusters and factors}

The four clusters are positioned on the three factors as described in table 2. Values shown in bold indicate the belonging of clusters to the factors. Cluster 4 is placed at the positive pole of 
the factor 1 (horizontal axis); cluster 1 and cluster 2 are placed on the factor 2 (vertical axis), respectively at the positive and negative pole; cluster 3 is positioned at the positive pole of the factor 3 (perpendicular axis to the plan created by the first two factorial axes).

\begin{tabular}{|l|r|r|r|}
\hline & Factor 1 & Factor 2 & Factor 3 \\
\hline Cluster 1 & -6.0440 & $\mathbf{2 9 . 5 5 7 2}$ & -7.7160 \\
\hline Cluster 2 & -23.2999 & $\mathbf{- 2 3 . 7 7 5 7}$ & -0.8314 \\
\hline Cluster 3 & 9.2259 & 1.2189 & $\mathbf{2 1 . 4 4 2 0}$ \\
\hline Cluster 4 & $\mathbf{2 4 . 9 6 0 2}$ & -14.5012 & -8.9943 \\
\hline
\end{tabular}

Table 2. Distribution of the clusters in the factorial axes

\section{Composition of the clusters}

Let us see now the dense words which compose each cluster.

\section{Cluster 1}

The first cluster results composed of the following dense words: people, believe, world, grow, impact, young people, engineer, think, history, ready, life, power, accelerate, successful, population, transform, perspective, industry, bring, imagine, convergence, cut, threat, explain, give up, honour, speak, promise, group, right.

\section{Cluster 2}

The second cluster is composed by: hope, big, price, stress, European countries, pay, inflation, lower, drop, high, growth, strong, reform, AfDB (African Development Bank), push, value, achieve, Greece, good, expect, fall, trade, IMF (International Monetary Fund), minimum level, shock, Africa, service, Human Genome Project, protect, policy, interest, GDP, economy.

\section{Cluster 3}

The third cluster gathers the following dense words: project, strengthen, invest, budget, fund, manage, provide, need, advantage, competition, tax, fail, boost, cope, employee, prepare, forecast, freedom, rule, know, crisis, solve, best, woman, raise, access, reform.

\section{Cluster 4}

The dense words composing the fourth cluster are: IDB (InterAmerican Development Bank), member countries, sure, respect, IDB Group (InterAmerican Development Bank Group), establish, make decisions, impact-investors, Latin America \& Caribbean, decision, understand, 
benefit, know, promote, tool, making money, Region, allow, have to, implement, investor, finance, impact-investing, provide, project, strengthen, seek, vis à vis, CEO, adopt, approve, full, crisis, ensure.

In figures 2-4 are shown the dense words composing the clusters obtained by the statistical data analysis, subdivided for the factor of belonging. On the same line are shown the dense words with the same value of chi-squared.

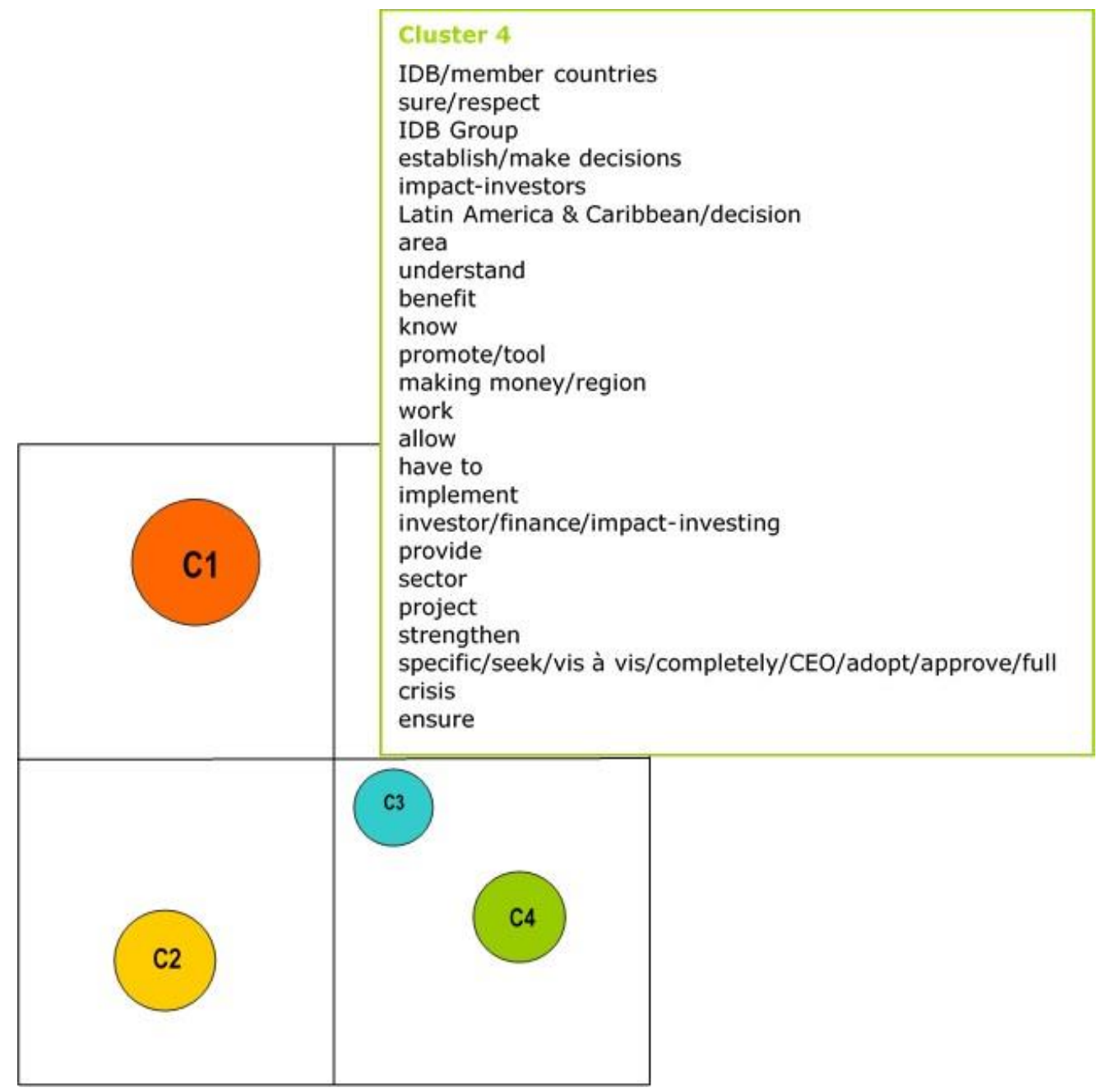

Figure 2. Dense words composing the cluster 4, on the first factor 


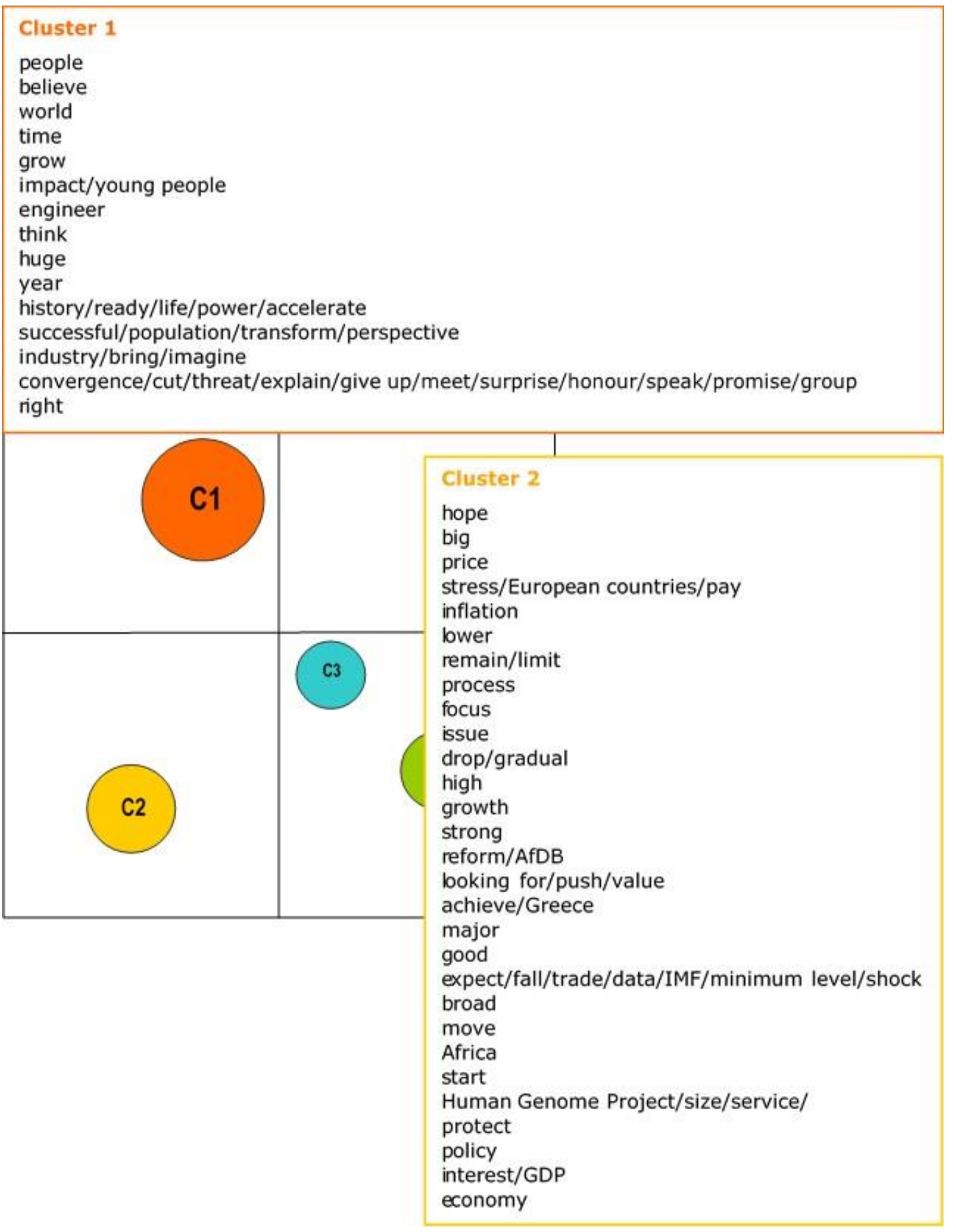

Figure 3. Dense words composing the clusters 1 and 2, on the second factor 


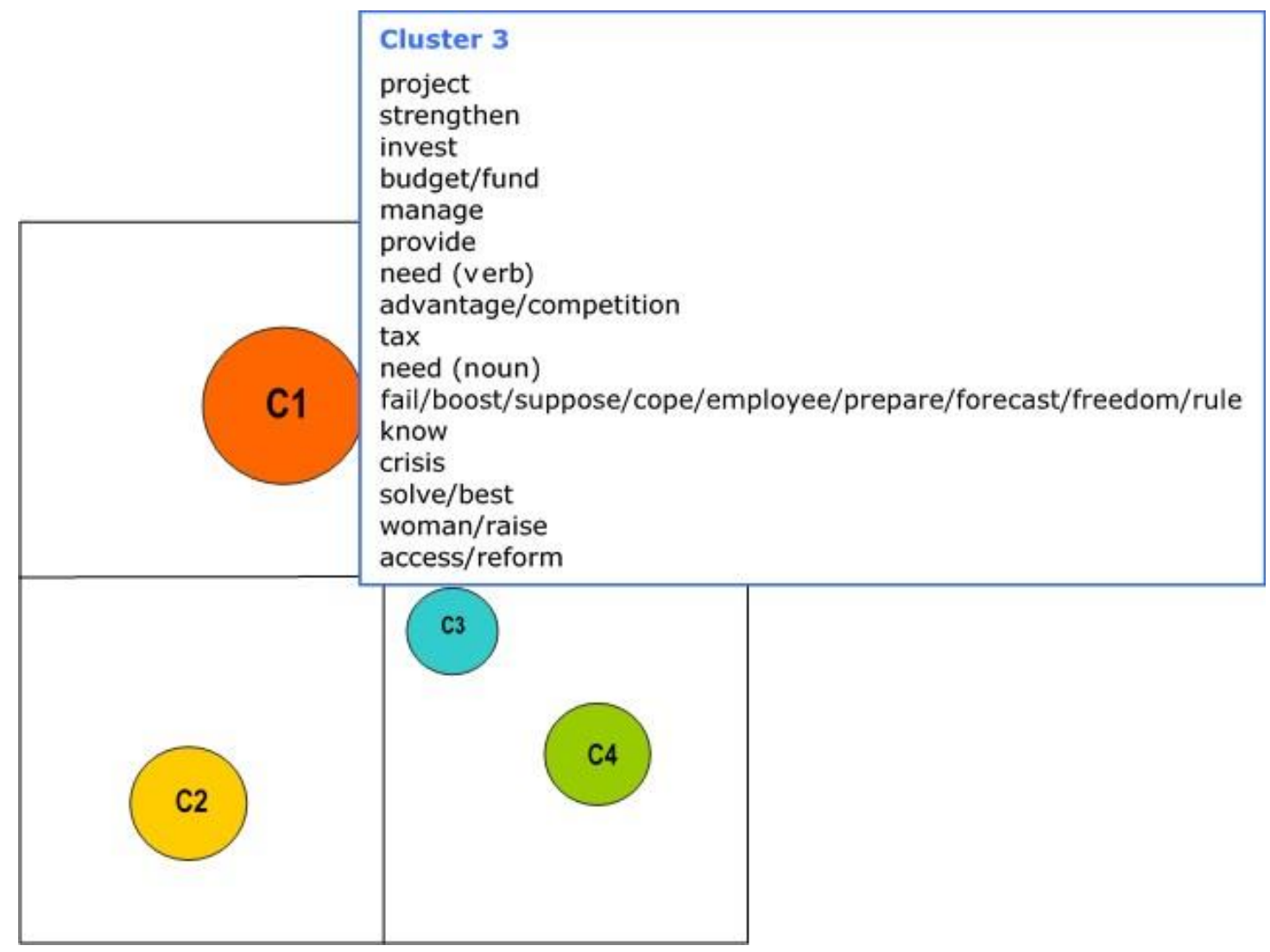

Figure 4. Dense words composing the cluster 3, on the third factor

\section{Relationship between texts and cluster}

The texts of each member of the World Economic Forum Board of Trustees contributed in different measure to the composition of the clusters of dense words, as shown in figure 5. For each cluster key contributors can be identified as follows: the president emerita and professor of neuroscience at the Massachusetts Institute of Technology (MIT), the chairman and chief executive officer of First Eastern Investment Group and the chairman of the Centre for Global Industries WEF for cluster 1; the president of African Development Bank, the governor of Bank of England, the managing director and the deputy managing director of the International Monetary Fund (IMF) for cluster 2; the chairman of Bain \& Co. and the chairman and chief executive officer of Sberbank for cluster 3 and the president of Inter-American Development Bank and the chairman and chief executive officer of Renault-Nissan Alliance for cluster 4. 


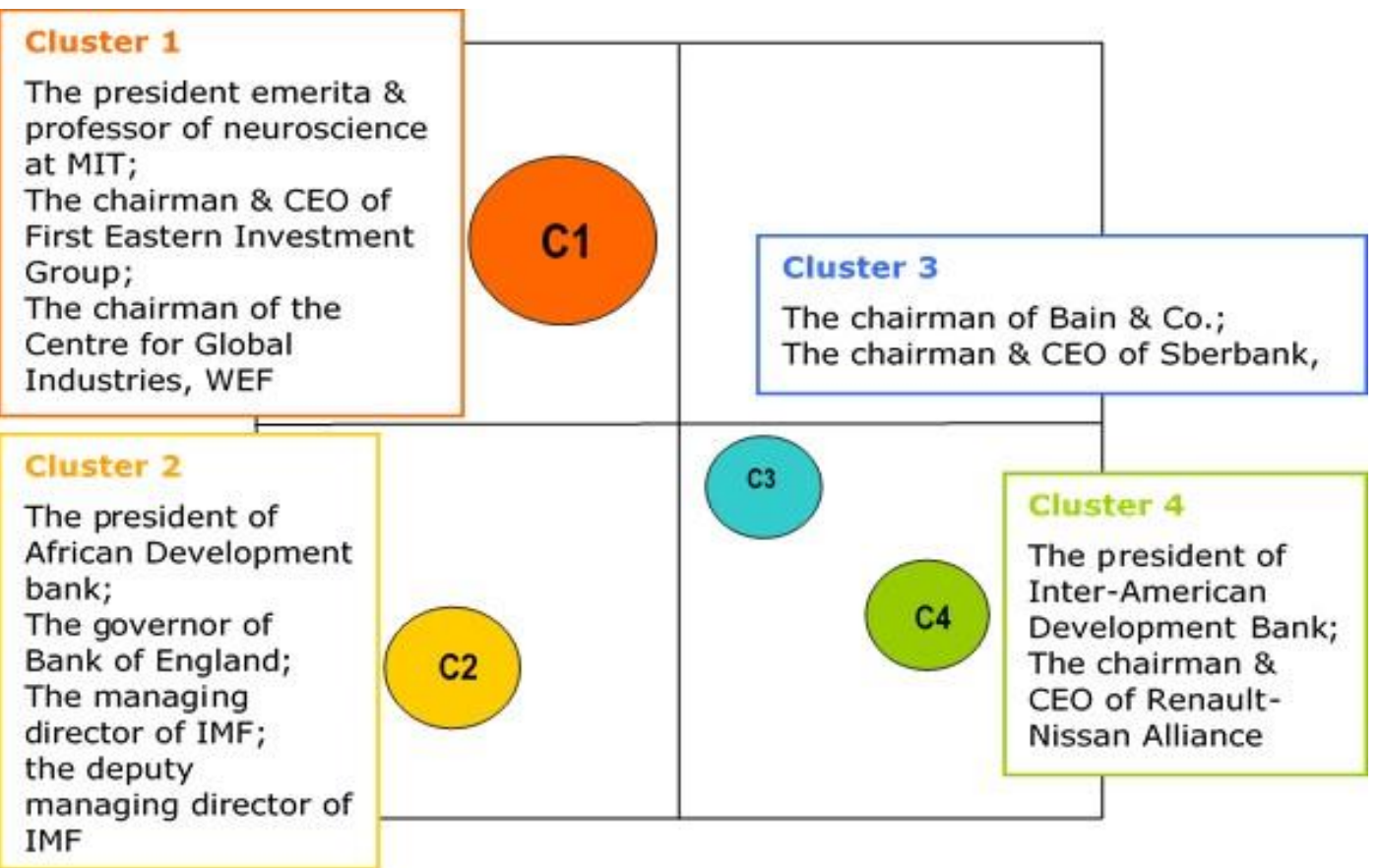

Figure 5. The main contributors to each cluster

\section{Psychosocial components of the Davos elite's discourse on globalization}

The interpretation of the co-occurrence of dense words within the clusters and the interactions among clusters, performed through the etymological analysis and the set of social relations models proposed by Carli and Paniccia on the basis of their theory of collusion (Carli \& Paniccia $2002,2003) v i$, allowed to identity the characteristics of the cultural dimensions composing the symbolic representation of globalization of the Davos elite, the socio- organizational dynamics that these dimensions produce at social, economic and political leveland some hypothesis of change for the development and improvement of these dynamics in aperspective of more productive and fair global social coexistence.

Let us start the description and discussion of these elements from the analysis of the cultural dimensions characterizing each cluster.

\section{Cluster 1}

The cultural dimension represented by the first cluster refers to the conceptual system of beliefs which should orient the meaning of life in the globalization age for the Davos elite, as a premise for the maintenance of its power, on the basis of the following elements:

- a negative representation of the other, conceived as a featureless anonymous mass of persons acting solely on the basis of emotional factors (such believing in someone or something), conceived as opposed to rational ones; 
- the proposition of three main symbolic frames for the attribution of meaning to life experiences in the globalization age, expressed by the words world, time and grow;

- the role of a form of thought and knowledge based on a technocratic approach oriented to impact people's life (especially that of young people) and thus take possession of them through the proposition of models of life based on readiness, success and power and the consequent transformation of their perception of reality, in relation to the interactions among the dense words engineer, impact, young people, think, history, ready, life, accelerate, power, successful, population, transform, perspective, industry, bring and image;

- the promotion of a pensée unique through the means of the rhetoric of promises and honour (as the respect of the constituted order), aimed at regrouping and keeping together things and persons for similarity, eliminating any divergent position which could threat the status quo, with reference to the dense words convergence, cut, threat, explain, give up, speak, promise, group;

- the definition of this way of proceed as a dogmatic value to respect, according to the dense word right.

\section{Cluster 2}

The cultural dimension represented by the second cluster appears focused on a manipulative way of organizing and managing social systems on the basis of the following elements:

- the construction of a messianic expectation (as metaphor of the come of the saviour messiah in the Judaic tradition) and, thus, of a passive and dependent approach to the dimension of bigness, here represented by the international financial institutions (such as the African Development Bank and the International Monetary Fund) and the big science approach of projects like the Human Genome Project;

- the proposition, as inevitable and necessary, of the negative consequences of the international financial institutions' messianic intervention represented as the risk of failing in the pursuit of the growth and strength based ideal of development, expressed by the threat of inflation and the imposition of living conditions to the limits of survival (e.g. Greece situation), which put under stress the European countries;

- the predominance of the economic factor in determining public policies, under the dogma of free market and personal gain, according to the meanings suggested by the interactions among the dense words policy, interest, GDP and economy. 


\section{Cluster 3}

The cultural dimension represented by the third cluster revolves around the idea of competition as one of the main drivers of social life and the conditions to pursue it, represented by the following elements:

- the commitment to strengthening the ability to provide, invest and manage budget and funds;

- a warped view of competition based on the search for conditions of privilege to successfully compete, strictly linked to the negative perception towards taxes, seen as an authoritarian imposition that limits the satisfaction of one's needs;

- the consequent need of developing a social order based on the idea of freedom, conceived as absence of restraints to one's expansion;

- the key importance of cognitive tools concerning capacities like perceiving, distinguishing, choosing and establishing in the pursuit of this ideal of success, referring to the dense words know, crisis, solve and best;

- the increasingly relevant role of women in facilitating the access to the needed reforms to spread the value of competition.

\section{Cluster 4}

The cultural dimension represented by the fourth cluster results based on the main role of finance in the organization of human life, articulated in the following elements:

- the role of supranational finance institutions (e.g. InterAmerican Development Bank Group) in producing a new sort of colonialism through the form of development aid based on providing sureness (psychological, other than economic) through financings, in exchange of the gradual expropriation of the local political and economic power, with reference to interactions among the dense words IDB, IDB Group, member countries, Latin America \& Caribbean, sure, respect, establish, make decisions, decisions;

- the role of finance as the dominant model to organize life and the main strategy to solve contemporary socio-economic and environmental problems, on the basis of the role of money in creating a relational model based on the transformation of the other in a dependent debtor, with ever less decisional power;

- the effects of innovative financing schemes, such as impact investment, which, despite being aimed at generating social benefit (alongside financial returns), actually becomes a way for taking possession of the last remaining fields of public intervention such as welfare, health, education and energy; 
- the need of integrating the development assistance recipient countries into the myth of making money in their regions (in order to make of these regions a source of economic value);

- the tendency to interface solely with the business elite of these countries as a way to ensure the elite system from the effects of possible crisis (with reference to the dense words vis à vis, completely, CEO, crisis and ensure).

\section{Discussion}

The main common feature that links all these cultural dimensions is the lack of democracy in the decision-making processes, which manifests itself both at relational and organizational level. At relational level, this is expressed by specific patterns of the emotional and motivational dynamics that drive social interaction.

The specific emotional pattern has been detected through the Carli and Paniccia's model of neo-emotions, which is based on the identification of two possible forms of social interaction: one oriented to the creative and productive exchange with the other, which eases the development of the systems of social coexistence, and one aimed to possess the other through different forms of emotional dynamics based on claiming, controlling, distrusting, provoking, obligating, complaining and worrying, which instead obstacles the development of the systems of social coexistence. The specific emotional pattern arising from this analysis is characterized by the following elements:

- the claim of imposing a specific dogmatic vision of reality based on a negative connotation of the elite's counterpart (represented as an unreliable and emotions driven mass) and on the role of concepts like global, growth, technology, believe, power, acceleration, big, success, honour, respect, rightness, hope, strength, finance, investment, competition, freedom, deregulation and crisis in shaping the sense of life and driving human action;

- the provocation expressed by this claim, in terms of legitimation of the negative effects implicit to this vision of things, represented by the risk of the prevail of a pensée unique, the loss of local political and economic power related to the international financial institutions' intervention, the predominance of a financial logic in the management of socio-economic and political issues and of an ever more deregulated economic competition;

- the fulfilment control of the obligations deriving from this kind of life's organization, in terms of conditioned choices and of even only the possibility of thinking alternative opportunities of action (e.g.: the possibility of alternative visions of development and of 
socio-economic and political problem-solving approaches alternative to the predominant financial ones);

- the worries and complaints against limits and rules perceived as constraints to the elite's desired expansion of power, expressed by the interactions among the dense words advantage, competition, tax, freedom and rule.

These emotional dynamics reveal an approach to social relations oriented to possess the other rather than to a productive and creative exchange with it. This can be read as an expression of a fear towards the other and its unpredictable unknown diversity, represented for instance by its possible behaviours not compliant with one's expectations (not necessarily hostile ones), and thus threatening the possibility of automating the relationships with it. The orientation to the relationship with the other as a productive and creative exchange, instead, requires a greater involvement in the relationship with it and a better relational competence to interact on the basis of reciprocal needs and expectations. To this regard, let's think, for instance, to the possibility of seeking for alternative strategies to the intervention of financial institutions like IMF, in the case of debt crisis, and to the use of financial instruments like impact-investment, to face socio-economic or environmental problems (e.g. making recourse to different problemsolving strategies based on bottom-up methods of participatory local community development), and to the reaction that this could produce in the upholder of the status quo. This relational orientation to possess the other can arise from a representation of it as enemy, which can lead to attempt to transform it into a taken for granted well-known friend, assimilated to one's own categories in the effort of eliminating its unpredictability and the risk of its possible manifestations of dangerousness. This, however, inevitably implies denying differences and thus missing the opportunities they offer.

The motivational pattern has been detected under the McClelland's human motivation theory (McClelland 1958, 1987), that is based on three main motivational factors to social relations: the needs for power (oriented to control and influence the other), affiliation (oriented to belong to a group, developing positive affective relationships within it) and achievement (oriented to accomplish goals). It looks characterized by the prevalence of the need for power, as dominant social motivation, that articulates itself into three dimensions: a hierarchical pattern that counterposes elite and people, the big and who hopes in it, CEOs and employees, backers and recipients. This represents a polar dynamic of belonging to/exclusion from the system of power, based on the affective dependency of the other (also expression of the motivational need for affiliation), induced by the logic of financial support to development programs, and a manipulative dynamic based on the contraposition between appearance and reality, as evidenced by the contrast between the positive image of development assistance policies and 
the expropriation of local political and economic powers produced by its exclusively financial logic.

As far as concerns the organizational level, the lack of democracy reveals itself in a dogmatic a priori conception of the international (supranational) financial institutions system (here exemplified by IMF, AfDB and IDB), which looks like grounded in an unquestionable mythical dimension that put it out of time and context and hence appears as immutable and little inclined to change and improvement. The foundation myth of this system can be traced back to Bretton Woods agreement of 1944, which laid the foundations of the current age of globalization by defining the monetary and financial basis of development of the international trade liberalization and that represents one of the few points of general consensus upon which the current system of global social coexistence was based, in terms of a new social order of peace and development, after world war II, and the economic crisis of 1929. The functioning of these supranational organizations seems, indeed, to be almost exclusively based on the following elements:

- the social mandate provided by the respect of socially grounded systems of values compliant with the ends of these organizations; a sort of social obligation to turn to them to face development and public debt problems, which is based on the general belief (strictly linked to the myth of Bretton Woods) that this is the natural and right way to do, just like one turns to a doctor when he's ill, as the only way of acting thought possible;

- the expected compliance to their self-referentially defined rules of service delivery, separated from the specific needs of their beneficiaries;

- the substitutive function, by them played in their interventions, based on a technocratic spirit by virtue of which technicians (the experts) substitute themselves to the users of their services (i.e. the recipient countries of their financings), expropriating these latter of their own political and economic decisional power, instead of supporting them in autonomously producing endogenous, self-determined, self-ruled and self-sustainable pathways of local development;

- the transformation of their beneficiaries from active/autonomous subjects, with specific needs, desires, goals and expected products and outputs, to passive and dependent users of their own self-referential procedures.

In this way these organizations operate without a real commission and demand of services from their beneficiaries, thus not addressing nor being held accountable for the needs, expectations and goals of these latter and for the efficacy of the services they provide to them.

\section{Conclusions}


On the basis of these results several intervention strategies can be proposed to improve the above outlined scenario. The implementation of these strategies, however, requires an active and accountable involvement of all the global elite's counterparts (people, when they act as active and accountable citizens, and their civil organizations; but also politicians and governments, when they act as effective representatives at the service of their commissioners: citizens and their communities).

The main goal to be pursued at relational level concerns the real participative definition and implementation of new rules of the game for social coexistence that allow to contain the possible manifestations of dangerousness within relationships between belonging system and stranger, conceiving the former as something prevalently functioning on the basis of a similarity principle, through dynamics of power and affiliation, and the latter as who entail the confrontation with the other's diversity and the need of reciprocal social interactions (Carli \& Paniccia 2002). This could be made, for instance, by boosting institutionally funded and selffunded projects, as well as media productions (e.g. music, film, TV), aimed at creating a new social imagery, oriented to this goal, in all the contexts of social experience: from education and caregiving, to work and free time. To pursue this goal requires to configure the other not anymore as enemy or well-known friend, but as unknown friend to become acquainted with in a relationship of reciprocal exchange, creatively producing together for the common good; thus also unchaining the production of goods and services from the self-referential end of profit (for the upper class) and surviving (for the middle and low classes), by developing a new ethic of productive cooperative doing. This model of social relations allows to unleash one's creative power (as power of doing), avoiding the risk of transforming one's creative impotence into forms of power over someone or something, as forms of possession of the other acted by influencing it to do what probably one feels not able or capable to do by oneself. But this requires the development of a relational and emotional competence to manage it.

Regarding the motivation to power as main driver of social relationships, the passage from a relational model grounded in the power over the other - linked to the need of possessing it to control its possible dangerousness - to one oriented to the productive exchange with the other - connected to the representation of the relationship with it as a reciprocal opportunity - allows to by-pass the hierarchical model of relationship with the other, by focusing on goals and products of the relationship with it and on the development of the competencies necessary to pursue them effectively, such for instance the capacity of dialogically interact with the other in order to understand its needs, expectations, values, desires and goals, to communicate to make understand the own ones and to negotiate to produce something reciprocally valuable. Consequently, also the dynamics of belonging, prevalently grounded in the self-referred emotions of power and affiliation - that bring to control the other and to make it dependent - 
can evolve, moving from the model of possession of the other to that of exchange with it. As a result, also the manipulative forms of power can be contrasted, (such as the current forms of development assistance that lead to the expropriation of local power), since the power becomes shifted towards the more creative construction of the common good.

At organizational level, the main objective of improvement concerns the passage from a compliance based logic of action to an approach based on commonly agreed goals and products, regarded as means of verification of the effectiveness of social action. This would consent to move from an organizational functioning of the supranational financial institutions entirely grounded in the social mandate - without any real demand by their recipients nor product socially evaluable in terms of common goods - to one driven by the demand of products and services verifiable by their recipients, on the basis of the needs and goals of these latter. As a result, the recipients of the supranational financial institutions' intervention could increase their active role in the relation with the technical function of these latter, which hence could be oriented to integrate the recipients' decisional power, facilitating the development of their competences in the autonomous achievement of their own goals. This requires questioning, in ever more dialectical and argumentative ways, the dogma of the economic development vision proposed by the global elite and to work on the definition and implementation of alternative hypothesis and models to pursue what the economic historian karl Polanyi named the substantive function of economy: the interchange between man and its natural and social environment to the aim of providing the material means to satisfy human's needs, in contraposition to its formal function of searching for the maximum individual profit, attributed to it by the economic science on the basis of the paradigm of rational choice, proposed as a universal (economic) law (Polanyi 1944). But Polanyi argued, on the basis of his studies of economic history in the first half of the last century, that this law solely represents the specific historical and socio-cultural reality of the market capitalistic economy (which moreover looked as an anomaly in the history of economy), produced by social motivations and meaning that actors attribute to it, on the basis of on a utilitarian conception of human action. He sustained that the economy is embedded into a social reality of relationships and shared meanings through which it is shaped (Polanyi 1944). According to the sociologists Berger and Luckmann (1966), it can be conceived as a social construction and as such, by the same way, can be changed and improved. Thus becomes fundamental culturally act to re-embed economy into its social context, in order to support the process of change here proposed. This also means to question the mythical ground of the supranational financial institutions' architecture represented in this study by International Monetary Fund (IMF) and development banks: the myth of Bretton Woods, which founded the currently ongoing global political economic order and system of coexistence on the basis of capitalism and market globalization process, that however looks to be no longer effective in dealing with the current challenges to social 
coexistence posed exactly by that globalization it contributed to boost. It would, thus, be necessary to propose a new deliberative stage for the foundation of a new social covenant with the real participation of all the concerned parties - not only the elites - on the basis of a new key rationale for the construction of a pacific and productive social coexistence, not only rooted in economic logics. Finally, in order to push this process of change of the Davos elite's organizational culture, it would be necessary that the beneficiaries of the international financial institutions change their attitude toward them, acting as commissioning party requesting services from these organizations on the basis of their specific needs, goals and expected products, in relation to possible specific endogenous pathways of development. These needs, goals and expected products represent, indeed, verification means by which to assess the effectiveness of these organizations in fulfilling their proposed aims and to promote change and improvement of their ways of functioning; by this way it's possible to produce a transition from the mythical image of these organizations - which looks grounded in the Bretton Woods' myth - to one oriented to answer to the reality's demand of people and social systems. This latter way of acting can be ked back to the psychoanalytic principle of reality, which expresses the ability to act on the basis of an assessment of the external reality of the world, in contraposition to the pleasure principle - which looks to rule the current functioning of these organizations - that is oriented instead to the satisfaction of biological and psychological instinctual needs, with a focus on the internal reality. The precondition to advance in this direction is the change of the social image of the elite's counterpart by overcoming the negative connotation attributed by the elite referring to them as people, term that is etymologically related to that of plebs, referring to the contraposition between plebeian (the low social level) and patrician (the higher social level) in the ancient Rome. This change can be pursued by recuperating the sense of the Greek word démos, referring to the democratic governing power of citizens. Thus reconfigured, in terms of global citizenship, the elite's counterpart can regain decisional and self-ruling autonomy and boost bottom-up democratization of government political systems - in terms of both participative and representative democracy - in a perspective of a collective and shared construction of the common future. This entails recovering the sense of public good, conceived as pertaining to the collectivity, in contrast to the private good, referring to an exclusive possession, that moreover deprives someone of something. The pursuit of this process of cultural transformation requires the development of specific competences, oriented to the development of an active and aware citizenship: this can become, for instance, the goal and the product on which to rebuild the sense of the social purpose of public education and of its productive efficacy, which also have been heavily undermined by globalization. 


\section{References}

Abric, J.C. (Ed). (1994). Pratiques sociales et representations. Paris: Presses Universitaires de France.

Benzécri J.P. (1981). Pratique de l'Analyse des donne linguistique et lexicologie, Paris: Dunod.

Berger, P. L. \& T. Luckmann (1966), The Social Construction of Reality: A Treatise in the Sociology of Knowledge, Garden City, NY: Anchor Books.

Berry, C. (2008). International political economy, the globalisation debate and the analysis of globalisation discourse. Working papers, University of Warwick. Centre for the Study of Globalisation and Regionalisation.

Berry, C. (2011). Globalisation and ideology in Britain: neoliberalism, Free Trade and the Global Economy. Manchester: Manchester University Press.

Blumer, H. (1969). Symbolic Interactionism. Perspective and Method. Englewood Cliffs: Prentice-Hall.

Bolasco, S. (1999). Analisi multidimensionale dei dati. Metodi strategie e criteri di interpretazione. Roma: Carocci.

Burr, V. (1995). _An introduction to social constructionism. London, UK: Routledge.

Cameron, A. \& Palan, R. (2004). The Imagined Economies of Globalization, London: Sage.

Carli, R. (1987). L'analisi della domanda. Rivista di Psicologia Clinica, 1 (1), 38-53.

Carli, R. (1990). Il processo di collusione nelle rappresentazioni sociali, Rivista di Psicologia Clinica, 3, 282-296.

Carli, R. (1995). II rapporto Individuo/Contesto. Psicologia Clinica, 1 (1), 5-20.

Carli, R. (2001). Culture giovanili. Proposte per un intervento psicologico nella scuola. Milano: Franco Angeli.

Carli, R. \& Giovagnoli, F. (2011). A cultural approach to clinical psychology: Psychoanalysis and analysis of the demand. In S. Salvatore \& T. Zittoun (Eds.), Cultural psychology and psychoanalysis: Pathways to synthesis (pp. 117-150). Charlotte, NC: Info Age Publishing.

Carli, R. \& Paniccia, R. M. (2002). L'analisi emozionale del testo. Uno strumento psicologico per leggere testi e discorsi. Milano: Franco Angeli. 
Carli, R. \& Paniccia, R. M. (2003). L'analisi della domanda: Teoria e tecnica dell'intervento in psicologia clinica. Bologna: II Mulino.

Carli, R., Paniccia, R. M., Giovagnoli, F., Carbone, A. \& Bucci, F. (2016). Emotional textual analysis. In Jason, L. \& Glenwick, S. (Eds.), Handbook of methodological approaches to community-based research: Qualitative, quantitative and mixed methods (pp. 111-120). New York: Oxford Univerisity press.

Charon, J. M. (2004). Symbolic Interactionism. An introduction, an interpretation, an integration. Boston: Pearson.

Duveen, G., \& Lloyd, B. (Eds.). (1990). Social representations and the development of knowledge. Cambridge, Cambridge University Press.

Farr, R. \& Moscovici, S. (Eds.). (1984). Social Representations. Cambridge: Cambridge University Press.

Freud, S. (1979). La teoria psicoanalitica. Torino: Boringhieri.

Gergen K. (2015). An Invitation to Social Construction. Los Angeles: Sage.

Glasersfeld, E. von (1995). Radical Constructivism: A Way of Knowing and Learning. London: Falmer Press.

Grasso, M. \& Salvatore S. (1997). Pensiero e decisionalità. Franco Angeli: Milano.

Hall, P. M. (2007). "Symbolic Interaction". Blackwell Encyclopedia of Sociology.

Harré, R (2002). Public sources of the personal mind: Social constructionism in context. Theory \& Psychology. 12 (5), 611-623.

Harré, R., \& Gillett, D. (1994). The discursive mind. London, Sage.

Hay, C. (1997). Anticipating Accommodations, Accommodating Anticipations: the appeasement of Capital in the Modernization of the British Labour Party. Politics and Society 25(2), 234-256.

Hay, C. (1999). The Political Economy of New Labour: Labouring Under False Pretences. Manchester: Manchester University Press.

Hay, C. (2002). Globalisation as Problem of Political Analysis: Restoring Agents to a "Process Without a Subject" and Politics to a Logic of Economic Compulsion. Cambridge Review of International Affaire 15 (3), 379-392. 
Hay, C. \& Marsh, D. (2000). Introduction: Demystifying Globalization. In C. Hay \& D. Marsh (Eds.) Demystifying Globalization (pp. 1-17). Basingstoke: MacMillan.

Hay, C. \& Rosamond, B. (2002). Globalization, European Integration and the Discursive Construction of Economic Imperatives. Journal of European Public Policy 9 (2), 147-167.

Hay, C. \& Smith, N. J. (2005). Horses for Courses? The Political Discourse of Globalisation and European Integration in the UK and Ireland. West European Politics 28 (1), 124-158.

Hay, C. \& Watson, M (1998). The Discourse of Globalisation and the Logic of NoAlternative: Rendering the Contingent Necessary in the Downsizing of New Labour's Aspirations for Government. In A. Dobson \& J. Stanyer (Eds.) Contemporary Political Studies, Vol. 2 (pp. $812-$ 822). Nottingham: PSA.

Jodelet, D. (1991). Madness and Social Representations. London: Harvester.

Kukla, A. (2000). Social Constructivism and the Philosophy of Science. London, Routledge.

Lancia, F. (2004). Strumenti per l'analisi dei testi. Introduzione all'uso di T-LAB, Milano: Franco Angeli.

Lebart L., Salem A. (1988). Exploring textual data. Dordrecht: Kluwer Academic Publishers.

Leeds-Hurwitz, W. (2009). Social construction of reality. In S. Littlejohn, \& K. Foss (Eds.), Encyclopedia of communication theory (pp. 892-895). Thousand Oaks, CA, SAGE Publications.

Lock, A. \& Strong, T. (2010). Social Constructionism: Sources and Stirrings in Theory and Practice. Cambridge University Press.

Lombardi, R. (2015), Formless Infinity. Clinical Explorations of Matte Blanco and Bion. London: Routledge.

Martell, L. (2010). Sociologia della globalizzazione. Torino, Einaudi.

Matte Blanco, I. (1975). The unconscious as Infinite Sets: An Essays in Bi-Logic. London: Gerald Duckworth \& Company Ltd.

Matte Blanco, I. (1988). Thinking, Feeling and Being. London and New York, Routledge.

McClelland, D. (1958). Methods of measuring human motivation. In J.W. Atkinson (Ed.), Motives in fantasy, action and society: a method of assessment and study (pp. 7-42). Van Nostrand: Princeton (NJ). 
McClelland, D.C. (1987). Human motivation. New York: University of Cambridge.

Mead, G. H. (1934). Mind, Self, and Society. Chicago: The University of Chicago Press.

Moscovici, S. (1961). La psychanalyse, son image et son public. Paris: Presses Universitaires de France.

Moscovici, S. (1963). Attitudes and opinions. Annual Review of Psychology, 14, 231-260.

Moscovici, S. (1988). Notes towards a description of social representations. Journal of European Social Psychology. 18 (3), 211-250.

Paniccia, R.M. (1992). Lo studio della collusione per una scienza della convivenza. In Caviglia G., Rubino A., \& Salvatore S. (Eds), Percorsi: pensiero e formazione in psicologia clinica (pp. 159-167). Roma: Kappa.

Petitta, L. \& Ghezzi, V. (2012). A holistic approach to the explanation of organizational behavior: the theory and pratice of "analysis of demand". In Ashkanasy, N.M., Härtel, C.E.J., \& Zerbe, W. J. (Eds.). Experiencing and Managing Emotions in the Workplace (pp. 105-137). Bingley: Emerald Group Publishing Limited.

Polanyi, K. (1944). The Great Transformation. New York: Farrar \& Rinehart.

Rayner, E. \& Tuckett, D. (1988), An Introduction to Matte-Blanco's Reformulation of the Freudian Unconscious and His Conceptualization of the inner World. In Matte Blanco I., Thinking, Feeling and Being (pp. 3-42). London and New York: Routledge.

Rayner, E. (1995) Unconscious Logic: An Introduction to Matte Blanco's Bi-logic and Its Uses. London and New York: Routledge.

Reynolds, L. T. \& Herman-Kinney, N. J. (2003). Handbook of symbolic interactionism. Walnut Creek, CA: AltaMira Press.

Searle, John (1995). The Construction of Social Reality. New York: The Free Press.

Stryker, S. (1980). Symbolic interactionism: a social structural version. Menlo Park: Calif Benjamin/Cummings Pub.

Steger, M. B. (2002). Globalism: The New Market Ideology, Oxford: Bowman and Littlefield.

Steger, M. B. (2005). Ideologies of Globalization. In Journal of Political Ideologies, 10 (1), 11 30. 
Steger, M. B. (2008). The Rise of the Global Imaginary: Political Ideologies form the French Revolution to the Global War on Terror, New York: Oxford University Press.

Wagner, W. \& Hayes, N. (2005). Everyday Discourse and Common-Sense: The Theory of Social Representation. New York: Palgrave Macmillan.

i The so-called Davos elite, in relation to the annual meeting of the world's elite held in Davos, Switzerland.

ii Words which are characterized by a strong capacity of evoking emotions independently from their position in the narrative structure of the text.

iii Carli and Paniccia (2002) proposed three areas of interpretative models which are based on the interaction individual-context. A first area is composed by models based on the symbolization of the body in the space, according to the polarities in/out, in-front/behind, tall/short, with reference to the dimensions of belonging, unfamiliarity, appearance, reality and power. A second area is based on the relationship with the other according to relational modalities of exchange-possession, where the possession of the other assumes the different forms of claim, control, provoke, obligate, distrust, complain and worry. A third area is composed bymodels which orient social relationships within organized groups according to the polarities fulfilment-objectives, given organization/construed organization, substitutive function/integrative function and social mandate/commissioning.

iv These dictionaries can be consulted at the web pages: www.wordreference.com and www.etymonline.com

${ }^{\vee}$ Here following their list by main position covered: Chairman of the Board, Nestlé, Switzerland; Chairman and Managing, Director, Reliance Industries, India; Chairman and Chief Executive Officer, Alcoa, USA; Managing Director, International Monetary Fund (IMF), Washington DC; Chairman and Chief Executive Officer, PepsiCo, USA; Founder, Executive Chairman of the World Economic Forum; Director, Global Security Research Institute, Keio University, Japan; Executive Chairman, Alibaba Group, People's Republic of China; Chairman of the Board and Chief Executive Officer, Sberbank, Russian Federation; Director, Yale Center for the Study of Globalization, Yale University, USA; Governor of the Bank of England; President, InterAmerican Development Bank, Washington DC; Visiting Scholar, Lee Kuan Yew School of Public Policy, National University of Singapore; Chairman and Chief Executive Officer, First Eastern Investment Group, Hong Kong SAR; Secretary-General, Organisation for Economic Cooperation and Development (OECD); President Emerita and Professor of Neuroscience, Massachusetts Institute of Technology (MIT), USA; Group Chief Executive, Standard 
Chartered, United Kingdom; Chairman, Bain \& Company, USA; Chairman, Centre for Global Industries (WEF grouping); Chairman and Chief Executive Officer, Renault-Nissan Alliance, France; Accel Partners, USA; Deputy Managing Director, International Monetary Fund, Washington DC; President, Ecole Polytechnique Fédérale de Lausanne (EPFL), Switzerland; President, African Development Bank (AfDB); Queen of the Hashemite Kingdom of Jordan; President, International Committee of the Red Cross, Switzerland. For further details see: https://www.occupy.com/article/infographic-who-are-davos-class (last access October, 18th, 2020).

${ }^{\text {vi }}$ Above described in note iii 